\title{
CREATION OF TERRITORIAL IDENTITY IN THE CHORVÁTSKY GROB MUNICIPALITY
}

Magdaléna Nemčíková, Veronika Kišová, Alfred Krogmann, Ján Veselovský

\begin{abstract}
Changes in perceptions of individuals' relations or society to a specific territory have been carried out ever before, but their recent acceleration has been even more pronounced due to both globalization and European integration. In the paper we identify and briefly analyze the most important factors and processes that influence the formation of the territorial identity in the Chorvatsky Grob municipality in Slovakia. We also deal with the subjective dimension of territorial identity which we analyze through the questionnaire survey. The most significant impact on the dichotomy between the autochthonous (Chorvátsky Grob) and allochthone population (Čierna Voda) has the process of suburbanization since the municipality is a part of the suburban zone of Bratislava City. Negative impacts on local identity are caused not only by enormous increase in the number of incomers but also by the eccentric (separated) position of the residential construction in the local part of Čierna Voda.
\end{abstract}

Keywords: territorial identity, Chorvátsky Grob municipality, suburbanization, allochthone population

\section{Introduction}

In today's global age, in addition to ubiquitous unification, we can observe the increasing trend of strengthening the autonomy and identity of regions (e.g. Catalonia, Lombardy and Veneto, etc.). Therefore, also perceptions of relations between individuals, companies to a particular territory are at the center of attention not only in geography. The topic of territorial identity, which in the sense of Paasi (2000) is understood as a social construct, acquires a new meaning in geographic research. Certain space with specific social, economic or developmental conditions becomes, according to Chromý (2003), the basis for shaping territorial identity. In the paper we deal with the study of territorial identity at the local level on the example of the municipality of Chorvátsky Grob in Slovakia.

\section{Methodology}

When evaluating the development and the state of the territorial identity of the Chorvátsky Grob municipality, we used the qualitative and quantitative 
research methods. From an objective point of view, we analyzed the territorial identity through a comparative analysis of relevant documents and information gathered by field research.

We applied the questionnaire and interview methods to investigate the territorial awareness (subjective dimension of identity) of the autochthonic (original) as well as the allochthone (immigrated) population of the municipality. The main priority was to find the satisfaction and opinion of the inhabitants on the environment in which they live. We obtained the data through an online questionnaire (18 open and closed questions) which could be shared through the Facebook social network in the community of the Chorvátsky Grob municipality. In addition, the inhabitants of the municipality were distributed to the mailbox asking for a questionnaire to be filled in using the QR code (Kišová, 2017). The summarization of the results of the questionnaire survey, which was attended by 210 inhabitants of the municipality, enabled us to identify not only the main problems, especially in the immigrant population, but also the level of their territorial awareness.

In the final part of the paper, we predicted the possible direction of the territorial identity of the municipality of Chorvátsky Grob based on the gathered findings.

\section{Theoretical background of the territorial identity}

The practitioners began to engage more intensely by the research of territorial identity in the 1980s. The reason for their interest could be, according to Nikischer (2013), that original cultural borders and identities face stronger pressure and crisis due to increasing interactions. The renewal of social stability thus requires the creation of new identities where the region or the relative spatial closeness appears as an ideal platform where new identities can be formed (Agnew, 2001). In the sense of Paasi (2003), the identity is understood as a social process. The spatial aspect of identity is dealt with by many authors, e.g. Paasi (1986, 2003), Vencálek (1998), Raagmaa (2002), Chromý (2003), Hasprová (2004), Kasala (2006), Bucher, Kunáková (2012), Odehnal, Šerý (2012), Nikisher (2013), Repaská et al. (2015) and others. The dialectical character of the relationship of man - space was taken into account by Paasi (1986) in constructing his "concept" of regional identity distinguishing the regional identity of the population (in terms of regional awareness) and the identity of the region. In line with this concept, we partially analyze the identity of the municipality of Chorvátsky Grob and the awareness of its inhabitants. In detail, individual dimensions of regional identity are characterized, for example, in studies by Paasi (1986), Chromý (2003), etc. The importance of regional identity is pointed out, for example, by Chromý and Skála (2010) who consider it a "soft" factor or regional development tool. The study of Ragmaa (2002) "Regional Identity in Regional 
Development and Planning" is also inspirational where he points to differences between regions with strong and weak regional identity.

\section{Development and the current state of territorial identity of the Chorvátsky Grob municipality}

Although the first written mention about the municipality dates back to 1214 (Monar), the important for the formation of the municipality identity was the year 1552 when Croats came to the municipality (the name of the municipality in this period - Horwat az Grwab). They came from the area between Sisak and Kostajnica. Chorvátsky Grob was part of a compact ethnic enclave in Western Slovakia, as evidenced by the record of visitation from 1634 and 1780 when the Croatian population was found in the municipality (Kropilák, 1977). The Croats began to settle in the territory of Slovakia after the Battle of Mohács in the year 1562. According to Botík (1996), about 80 settlements were settled in several waves while in 20 of them, including the today's Chorvátsky Grob, they formed the majority (Figure 1).

Figure 1: Croatian settlement in Western Slovakia in the 16th and 17th century

- municipalities with a majority of Croatian settlements + work place of the Croatian priest

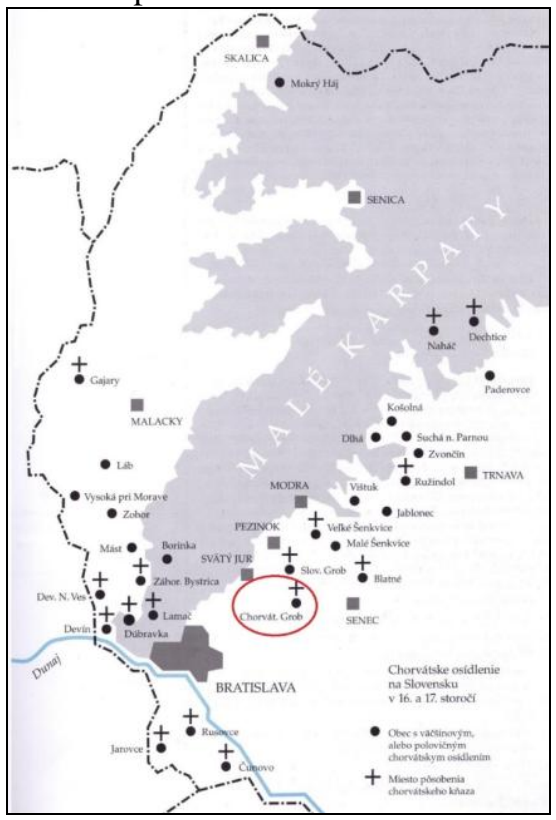

Source: Botík, 1996 
Despite the fact that the linguistic and ethnic affinity of the Croats affected the assimilation with the Slovak population and from the second half of the 19th century the Slovak population has already prevailed in the village, we can observe some "Croatian" impacts to this day. Croats used the so-called Gradišćansko Hrvatski language, which has preserved in Croatia only in glagolic language and is not used in Croatia today and it is a relatively archaic language. In Chorvátsky Grob, this language has preserved thanks to the old settlers especially in oral form in the form of kaykavsky dialect or in the form of the local names "Brige, Př́ćnice, Pri drahách Krče" (Kišová, 2017). It was important to keep the "Croatian identity" especially in the younger generation and the publication "Rječnika sela Hrvatski Grob - Dictionary of the Croatian Grob" (Figure 2) was published in 2004 in Zagreb (Takáč, 2004).

Although only 31 inhabitants $(0.82 \%$ of the total number (Population and Housing Census 2011) are being reported to the Croatian nationality, we can see a revival of Croatian culture since the 1990s. Once a week an education of Croatian language is organized on the pastorate through the lecturer from Croatia. The pupils of the local elementary school are getting acquainted with the Croatian culture through the cross-cutting theme of Regional and Multicultural Education. In addition, the language camps at the Adriatic Sea in Selce are organized for children. From 1989 there is also a folklore ensemble called Chorvatanka (Figure 3).

Figure 2: Dictionary of the Croatian

Grob

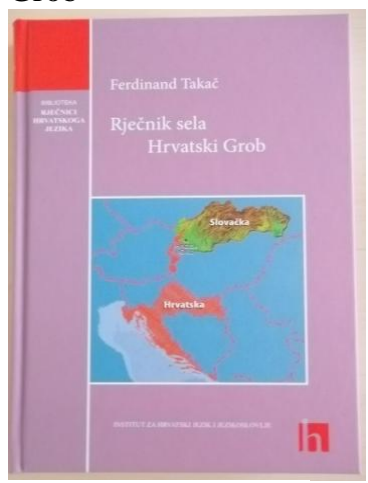

Source: Takáč (2004)
Figure 3: The Folklore ensemble

Chorvatanka

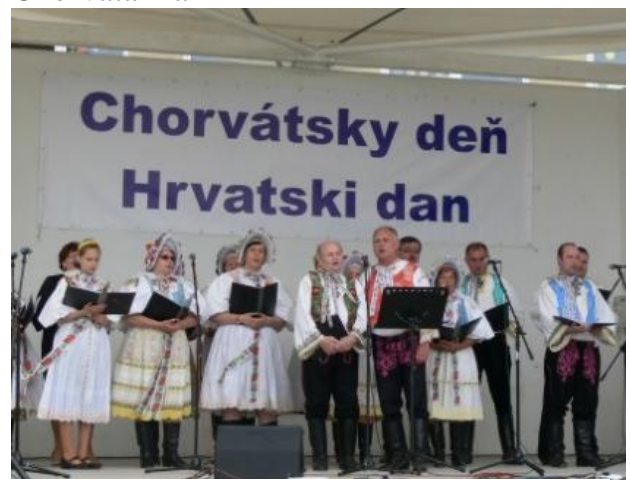

Source: Kišová (2017), Photo by Marková (2015)

Since 1990, the Croatian Cultural Association and since 2012 the Folklore ensemble "Malá Chorvatanka" contribute to shaping the territorial identity of the inhabitants of the municipality with a great degree. The "Croatian room" was founded thanks to the association where the clothing and objects representing the 
history and traditions of the municipality are place. The most important events that are involved in forming the "Croatian" identity in the Chorvátsky Grob community include the Croatian Ball, Croatian Culture Days and Croatian Day (Kišová, 2017).

Currently, thanks to the enormous suburbanization processes in the local part of Čierna Voda, we can observe a dichotomy in forming the territorial identity of the municipality as well as in its inhabitants. Čierna Voda or Chorvátsky Grob are considered by Šveda and Šuška (2014) the largest suburbs not only of Bratislava but also of whole Slovakia regarding the construction. Although the municipality became a symbol of suburban growth in Slovakia, it is also used as an example of negative manifestations of uncontrolled settlement development (Šveda, Šuška, 2014).

The modern process of shaping the territorial identity in Chorvátsky Grob can be traced back approximately from 2004 when the migration balance (net migration) began to increase continuously thanks to the suburbanization process. For example, the value of migration increase in 2004 was 81 while in 2007, it was already 345 . The highest values of the positive migration balance were in 2010 (554 - Statistical Office of the SR, 2017) and in this year the population of Čierna Voda suburb prevailed over the population of old settlers (Šveda, Šuška, 2014). The population of the municipality continues to grow (1,787 in 2004 and 5,615 to 30th September 2017) even though the value of the 2010 migration balance has not been overtaken so far. In 2016, the inhabitants of the local part of Čierna Voda accounted for $66 \%$ of the total population (Kišová, 2017). Apart from the number of inhabitants, also their age structure changes in the municipality. The two most numerous groups are age groups 30-40 years old and children under 10 years of age. We believe that these attributes of demographic indicators and the eccentric position of the Čierna Voda suburb will have a significant impact on the formation of the "separate - local" identity of this settlement unit.

\section{Identity (awareness) of inhabitants}

We agree with Šveda (2009) that the spatial segregation of the new settlers (allochthone population) in the local part of the Čierna Voda (the edges of the settlement units are currently approximately $1.1 \mathrm{~km}$ apart) does not contribute to their social integration and rather it leads to the generation of tension between them to the original population (autochthonous population), as evidenced by the results of the questionnaire survey.

The questionnaire was aimed at identifying the population with a place of housing. Of the total number of respondents, up to $70 \%$ were from Čierna Voda which corresponds to the current distribution of the population in the settlement units of the municipality. Only $5 \%$ of the respondents were the original inhabitants reflecting the current state that even in the local part of Chorvátsky Grob, the autochthonous population creates the minority. 
The questionnaire survey showed that residents feel that local government do not want to solve their problems, but, for example, only $16 \%$ of them attend the meetings of the municipal representatives. Most of the inhabitants of the municipality consider the most important solving for the traffic situation, the increase of the capacity in the school and kindergarten as well as the separation of local part of the Čierna Voda from Chorvátsky Grob. Up to $80 \%$ of residents expressed their satisfaction with the variability of organized events by the municipality. Even here is the duality - some actions are organized separately in every local part of the municipality which also does not contribute to the unification of the population. Most of the events are organized outdoors, as the municipality has no other building than the school dining room with sufficient capacity. Among the most frequent reasons for immigration, the respondents mentioned: suitable location for building a family house with a garden in the immediate vicinity of the capital city, affordable land parcels, sites close to nature reserves, peaceful rural environment and a rich past through Croatian roots (Kišová, 2017). Up to $9.5 \%$ of the respondents stated the reason for the immigration either as a return to the birthplace or to the family. Interestingly, it was found that up to $91 \%$ of respondents track information about the municipality through social networks. This may be due to the fact that $72 \%$ of respondents belong to the generations $\mathrm{Y}$ and $\mathrm{Z}$, often referred to as the "net" generation. With regard to the formation of the identity of the allochthone population, it is positive that up to $68 \%$ of respondents are willing to participate in improving the living conditions in the municipality.

\section{Perspectives for forming the territorial identity of the Chorvátsky Grob municipality}

The change in the process of shaping the territorial identity of the Chorvátsky Grob municipality occurred only recently in terms of time, but its intensity is very large. According to Šveda (2009), land compactness, developers' interest, building boom, and the following buyers' interest created from the Čierna Voda the first large-scale satellite in Slovakia with the features of Western European suburbs (small parcels, dense buildings, unconnected street grids, etc.). The formation of the community and consequently the formation of the identity of the population is negatively influenced also by the existence of the so-called gated communities (closed residential objects). In Čierna Voda, the state built such a closed residential suite for Kia Motors Slovakia s.r.o. managers, who live in isolation and do not care about the problems in the municipality (Kišová, 2017).

Moreover, important factor for the future development of the municipality is the fact that the real status of residents living in the Čierna Voda site is much higher (estimated $+2,000$ inhabitants) than official statistics (Lelkes, Schinglerová, 2014). The impacts of the under-regulated suburbanization are reflected on the 
inhabitants of the municipality, especially in the local part of the Čierna Voda every day (traffic jams, under-drainage sewerage, insufficient capacity of school and pre-school facilities, absence of public spaces, etc.) (Šveda, Šuška 2014, Lelkes, Schinglerová, 2014 and Kišová, 2017). The pressure of newcomers to solve the above-mentioned problems is causing the problematic relationship not only with self-government, but also with old settlers. Because of these accumulated problems, the first signs of immigrants leaving were recorded (for example in 2014 - 108 inhabitants, in 2016 - 119 inhabitants). The development of the municipality as well as the formation of its territorial identity will affected by the planned project "Park City Triblavina". Due to the fact that the project considers about 158 hectares in the cadaster of the municipality of Chorvátsky Grob to build a residential complex for 30,000 people, it is very difficult to predict what impact it will have not only on the identity of the municipality, but also on the entire region.

\section{Conclusion}

At present, we can observe not only acceleration, but also great variability in the process of shaping territorial identities, regardless of the scale of the territory. Greater emphasis is placed on socio-cultural elements than on the natural environment. There are differences in perceiving identity and identifying with someone, something, especially among the generations of young people called alpha, Z and Y (born after 1981), generation of the so-called baby boomers (19431960) and even the older generation "silent" generation. Differences in the understanding of identity are caused, in particular, by suburbanization processes and can be observed between old settlers and newcomers. Polarity is also reflected in the acceptance of old (e.g. tradition, language, architecture, geographical nomenclature ...) or new symbols (regional products, modern architecture ...) of particular territory.

The factors that have the most significant impact on the current formation of Chorvátsky Grob territorial identity as well as on its future development include: spatial incompatibility of the settlement, the unconventional and unregulated construction, disproportionate increase in the number of inhabitants, differences in the age composition of the population of the newcomers and old settlers, absence of genius loci of Čierna Voda and others.

The development of the territorial identity of the municipality of Chorvátsky Grob is currently in the forming phase and time will show if it will be a radical transformation occurs or its redefinition or only a "soft redirection" which will continue to follow on the previous character. It is very difficult to predict this development which depends not only on self-government, but also on the inhabitants of the municipality or developers and its future inhabitants of the municipality. In their mutual conciliation there is a presumption that the municipality of Chorvátsky Grob will not be only a sort of reminder in terms of Slovakia. 


\section{Acknowledgment}

The article was prepared within the grant project VEGA 1/0934/17 Land-use changes of Slovak cultural landscape over the past 250 years and prediction of its further development.

\section{References}

AGNEW, J. A. 2001. Regions in revolt. In Progress in Human Geography. vol. 25, no. 1 , pp. 103-110.

BOTÍK, J. 1996. Chorváti na Slovensku. Bratislava: Slovenské národné múzeum, 1996. 240 p. ISBN 80-85753-79-0.

BUCHER, S. - KUNÁKOVÁ, L. 2010. Identity as a context of geographical research, theoretical and methodological framework. In Geographic Review. ISSN 1336-7072, 2010, vol. 6, no. 1, pp. 6-23.

HASPROVÁ, M. 2004. Územná identita - rozvojový fenomén. In Zborník z V. vedeckej konferencie doktorandov a mladých vedeckých pracovníkov. Nitra: FPV UKF, 2004, Edícia Prírodovedec, 126. pp. 246-249. ISBN 80-8050-670-1.

CHROMÝ, P. 2003. Formování regionální identity: nezbytná součást geografických výzkumů. In Jančák, V., Chromý, P., Marada, M. (eds.) Geografie na cestách poznání. Univerzita Karlova v Praze, Př́rodovědecká fakulta, Katedra sociální geografie a regionálního rozvoje. Praha, 2003. pp. 163-178. ISBN 80-86561-10-0.

CHROMÝ, P. - SKÁLA, J. 2010. Cultural-geographical aspects in the development of borderland peripheries: an analysis of selected elements of territorial identity among residents of the Sušicko region. In Geografie. vol. 115, no. 2, 2010, pp. 223-246.

KASALA, K. 2006. Changing identity of locality: research methodology. In Geographic Review. ISSN 1336-7072, 2006, vol. 2, no. 2, pp. 709-723.

KASALA, K. 2012. Changing identity of Slovak localities. In Geographia Cassoviensis. ISSN 2454-0005, 2012, vol. 6, no. 1, pp. 33-36.

KIŠOVÁ, V. 2017. Forming the identity of Chorvátsky Grob municipality. Diploma thesis. Nitra: Faculty of Natural Sciences Constantine the Philosopher University in Nitra, 2017. 77 p.

KROPILÁK, M. ed. 1977. Vlastivedný slovník obcí na Slovensku I. 1. vyd. Bratislava: Veda, 1977. 526 p.

LELKES, G. - SCHINGLEROVÁ, A. 2014. Program hospodárskeho a sociálneho rozvoja obce Chorvátsky Grob na roky 2015-2020. Bratislava: Danube EuroConsulting, s.r.o., 2014.

NIKISCHER, R. 2013. Territorial Identity of the Inhabitants of Czechia and Slovakia. In Geografie. vol. 118, no. 3, pp. 243-264. 
ODEHNAL, J. - ŠERÝ, M. 2012. Regional Identity and its reflection in Czech Human Geography. In Dela. ISSN 0354-0596, 2012, vol. 38, pp. 25-37.

PAASI, A. 1986. The institutionalization of regions: a theoretical framework for understanding the emergence of regions and the constitution of regional identity. In Fennia. ISSN 0015-0010, 1986, vol. 164, no. 1, pp. 105-146.

PAASI, A. 2000. Territorial identities as social constructs. In Hagar International Social Science Review. vol. 1, no. 2, pp. 91-113.

PAASI, A. 2003. Region and place: regional identity in question. In Progress in Human Geography. vol. 27, no. 4, pp. 475-485.

POPULATION AND HOUSING CENSUS 2011. [online]. 2017. Accessed 25th September 2018. (http://datacube.statistics.sk/\#!/folder/sk/f46).

RAAGMAA, G. 2002. Regional Identity in Regional development and Planning. In European Planning Studies. ISSN 1469-5944, vol. 10, no. 1, pp. 55-76.

REPASKÁ, G. - VILINOVÁ, K. - DUBCOVÁ, A. - KRAMÁREKOVÁ, H. 2015. Residential identity as a phenomenon in the context of suburbanization (case study of suburbs of the city of Nitra). In Geographical Journal. ISSN 0016-7193, 2015, vol. 67, no. 2, pp. 107-126.

STATISTICAL OFFICE OF THE SLOVAK REPUBLIC. [online]. 2017. Accessed 19th September 2018. (www.statistics.sk).

ŠVEDA, M. 2009. Spatial structure of residential suburbanization in the suburban zone of Bratislava. In Acta Geographica Universitatis Comenianae. ISSN 1338-6034, no. 52, pp. 169-181.

ŠVEDA, M. - ŠUŠKA, P. 2014. On the causes and consequences of unregulated suburbanization in the hinterland of Bratislava: case study of Chorvátsky Grob. In Geographical Journal. ISSN 2453-8787, 2014, vol. 64., no. 3, pp. 225-246.

TAKÁČ, F. 2004. Rječnik sela Hrvatski Grob. Zagreb: Institut za hrvatski jezik I jezikoslovlje, 2004. 411 p. ISBN 953-6637-11-1.

VENCÁLEK, J. 1998. Protisměry územní identity. Český Těšín: Vydavatelství OLZA spol. s r. o., 1998. 207 p. ISBN 80-86082-10-5.

\section{RNDr. Magdaléna Nemčíková, PhD.}

Doc. RNDr. Alfred Krogmann, PhD.

Department of Geography and Regional Development

Faculty of Natural Sciences

Constantine the Philosopher University in Nitra

Trieda A. Hlinku 1, 94974 Nitra, Slovakia

E-mail: mnemcikova@ukf.sk, akrogmann@ukf.sk

\section{Mgr. Veronika Kišová}

Travel agency SATUR

Bratislava, Slovakia

E-mail: veronikakisova050@gmail.com 


\section{PaedDr. RNDr. Ján Veselovský, PhD.}

Department of Tourism

Faculty of Central European Studies

Constantine the Philosopher University in Nitra

Dražovská cesta 4, 94974 Nitra, Slovakia

E-mail: jveselovsky@ukf.sk 